\title{
Addressing health inequalities by using Structural Funds. A question of opportunities
}

Citation for published version (APA):

Neagu, O. M., Michelsen, K., Watson, J., Dowdeswell, B., \& Brand, H. (2017). Addressing health inequalities by using Structural Funds. A question of opportunities. Health Policy, 121(3), 300-306. https://doi.org/10.1016/j.healthpol.2017.01.001

Document status and date:

Published: 01/03/2017

DOI:

10.1016/j.healthpol.2017.01.001

Document Version:

Publisher's PDF, also known as Version of record

Document license:

Taverne

Please check the document version of this publication:

- A submitted manuscript is the version of the article upon submission and before peer-review. There can be important differences between the submitted version and the official published version of record.

People interested in the research are advised to contact the author for the final version of the publication, or visit the DOI to the publisher's website.

- The final author version and the galley proof are versions of the publication after peer review.

- The final published version features the final layout of the paper including the volume, issue and page numbers.

Link to publication

\footnotetext{
General rights rights.

- You may freely distribute the URL identifying the publication in the public portal. please follow below link for the End User Agreement:

www.umlib.nl/taverne-license

Take down policy

If you believe that this document breaches copyright please contact us at:

repository@maastrichtuniversity.nl

providing details and we will investigate your claim.
}

Copyright and moral rights for the publications made accessible in the public portal are retained by the authors and/or other copyright owners and it is a condition of accessing publications that users recognise and abide by the legal requirements associated with these

- Users may download and print one copy of any publication from the public portal for the purpose of private study or research.

- You may not further distribute the material or use it for any profit-making activity or commercial gain

If the publication is distributed under the terms of Article $25 \mathrm{fa}$ of the Dutch Copyright Act, indicated by the "Taverne" license above, 


\title{
Addressing health inequalities by using Structural Funds. A question of opportunities
}

\author{
Oana Maria Neagu ${ }^{\mathrm{a}, *}$, Kai Michelsen ${ }^{\mathrm{a}}$, Jonathan Watson ${ }^{\mathrm{b}}$, Barrie Dowdeswell ${ }^{\mathrm{c}}$, \\ Helmut Brand ${ }^{\text {a }}$ \\ ${ }^{a}$ Maastricht University, Duboisdomein 30, 6229 GT Maastricht, The Netherlands \\ b HealthCluster Net, Hoofdweg 146 II, 1057 DB Amsterdam, The Netherlands \\ c Management Centre Innsbruck, Universitätsstraße 15, 6020 Innsbruck, Austria
}

\section{A R T I C L E I N F O}

\section{Article history:}

Received 14 January 2016

Received in revised form

16 December 2016

Accepted 2 January 2017

\section{Keywords:}

Health

Health equity

Health inequalities

Structural and Investment Funds

Cohesion policy

\begin{abstract}
A B S T R A C T
Making up a third of the EU budget, Structural and Investment Funds can provide important opportunities for investing in policies that tackle inequalities in health. This article looks back and forward at the 2007-2013 and 2014-2020 financial periods in an attempt to inform the development of health equity as a strand of policy intervention under regional development. It combines evidence from health projects funded through Structural Funds and a document analyses that locates interventions for health equity under the new regulations. The map of opportunities has changed considerably since the last programming period, creating more visibility for vulnerable groups, social determinants of health and health systems sustainability. As the current programming period is progressing, this paper contributes to maximizing this potential but also identifying challenges and implementation gaps for prospective health system engagement in pursuing health equity as part of Structural Funds projects. The austerity measures and their impact on public spending, building political support for investments as well as the difficulties around pursuing health gains as an objective of other policy areas are some of the challenges to overcome. European Structural and Investment Funds could be a window of opportunity that triggers engagement for health equity if sectors adopt a transformative approach and overcome barriers, cooperate for common goals and make better use of the availability of these resources.
\end{abstract}

(c) 2017 Elsevier B.V. All rights reserved.

\section{Introduction}

Europe is diverse. Also the health status varies considerably between countries. Within the European Union there is a gap between "new" and "old" Member States, between

\footnotetext{
* Corresponding author at: Maastricht University, Department of International Health, Duboisdomein 30, 6229GT Maastricht, The Netherlands.

E-mail addresses: oana.neagu@maastrichtuniversity.nl, oana.m.neagu@gmail.com (O.M. Neagu),

kai.michelsen@maastrichtuniversity.nl (K. Michelsen), jonathan@healthclusternet.eu (J. Watson), barrie@dowdeswell.entadsl.com (B. Dowdeswell), helmut.brand@maastrichtuniversity.nl (H. Brand).
}

the north and south. At the same time, studies of health inequalities within countries highlight a larger divide on a subnational scale and in many cases a growing divide between regions $[1,2]$. The health status at national and regional level is correlated to the socio-economic status of the population, the relationship being much stronger for countries and regions with lower levels of GDP [3]. The consequences of the crisis and the austerity policies adopted by many EU countries increased the number of people living in poverty, affecting the health in the low socio economic groups, the vulnerable and excluded populations [4-7].

Health inequalities have become a concern for WHO Europe ("Health is Wealth", Health 2020) and the EU. 
Especially in EU documents from 2008-2009 the socioeconomic rational to reduce health inequalities emerged as a more powerful argument of securing people's access to most fundamental rights. Health inequalities and its consequences have been addressed in official communications, reports and working papers in terms of potential economic loss, health care expenditure, labour supply or labour productivity $[8,3,9]$.

The public health community has long recognised the need to address inequalities. Bridging the gap in health depends on health services but to a large extent to the determinants of economic success, social and political change and altered human behaviour [10-12]. Disparities in health status between places and people are influenced by the distribution of factors such as income, employment, environmental risks, living and working conditions, availability of food, access to education, access to ways of transportation, means of social participation [13-16]. However, and despite the discussions about "Health in all Policies" and "Whole-of Government" approaches, the public health community rarely engages with those who drive these determinants [17].

This paper discusses the case of the European Structural and Investment Funds (ESIF) which can provide important opportunities for the public health community to address and invest in actions that tackle inequalities in health.

EU Structural Funds (ESF), specially the European Regional Development Fund (ERDF) and the European Social Fund (ESF) have evolved into a well-established feature of regional development and planning and are now within the framework of European Structural and Investment Funds (ESIF). Since late 1980s their main aim has been to reduce regional economic and social disparities and to promote sustainable development across Europe. While being one of the most tangible EU policies, with almost a third of the total EU budget to sustain it, ESIF open up financial possibilities for investing in social determinants of health and sustainable health systems. Taking into account the austerity measures and their impact on public spending, ESIF can be an important resource, for some Member States perhaps the only source of new investment, towards achieving health objectives, transforming services and contributing to regaining economic stability [18]. Moreover, the overarching goals of ESIF have been to reduce regional disparities in income, wealth and opportunities. Therefore, they could represent a space for the public health community to engage with policies impacting health like social, labour or environmental policies. If public health is to ensure access and equity in health it needs to work with other sectors to address the determinants of health and reduce health inequities [19].

At the EU level, Member States have explicitly been encouraged to make smarter use of these financial programmes [20,21]. During the 2007-2013 programming period, health was identified as a priority intervention area within the ERDF and ESF framework. However, absorption rates of Structural Funds for health have been reported rather low with the public health sector playing a marginal role in the implementation of the Cohesion Policy [22]. In 2010, the European Commission proposed a new path for development with clear objectives to be reached, a stronger link with its funding programmes and stricter economic governance. Under this framework the new Structural and Investment Funds aimed to address the economic development challenges Europe had been confronting itself since the start of the financial/economic crisis while sustaining social cohesion. The policy spectrum includes a new broad set of interventions to achieve smarter, more sustainable and more inclusive growth. However, although health equity is strongly linked to these objectives, health as such was not highlighted as an independent investment priority anymore.

How to maximise ESIF potential to reduce health inequities? Can the experiences with utilization in the previous period provide better guidance to make use of their availability? Have the changes in regulatory framework created more opportunities or value for health equity investments or on the contrary more challenges? This article will address these questions by looking back and forward at the 2007-2013 and 2014-2020 financial periods and analysing the matrix of opportunities for investment in health equity.

Through this mapping exercise the article will bring a contribution to a theme that is not often investigated scholarly. Academic research has usually focused on health equity as a public health goal or on Structural Funds as an investment framework for economic development and cohesion, but rarely have the two fields been bridged [23]. Many projects were funded through the previous EU Health Programme 2008-2013 to provide tools, guidelines, support and capacity building to Member States on how to employ Structural Funds for health and health equity (euregio3, 2015) [24-27]. However, not many scientific publications emerged as a consequence.

Therefore, the article informs the development of health equity as a strand of policy intervention, regional planning and research. The findings are of direct practical relevance for policy-makers as well. One of the aims of the paper is to contribute towards more and better use of ESIF for investments in health in the future. One of the explanations for rather low absorption rates of Structural Funds is lack of know-how to make use of their availability in the context of improving health status. The present article will therefore address this predicament while further research will look into the capacities of the policy makers and the public health community to make use of these financial opportunities.

\section{Materials and methods}

This article draws on the outcomes of two European funded projects aiming to support regions in using Structural Funds for health and health equity: EUREGIO III (2009-2011) and HealthEquity2020 (2013-2015). The first represented an important source of information on policy implementation during the period of the Lisbon Strategy (2000-2010) and the crossover to the Europe 2020 Agenda. Specifically, it explored and assessed the use of Structural Funds for health in the 2007-2013 period. It systematically collected evidence from over 30 projects from across the EU27 funded through Structural Funds and ultimately developed 10 case examples meeting rigorous assessment 
criteria. These were compared with another group of 8 case studies containing non-SF funded projects but with high relevance to regional structure planning applicable to EU Member States and their regions.

Taking into account the rapidly changing circumstances in the health landscape during the programming period of 2007-2013 the case selection aimed to be a dynamic process responding to significant trends and factors at that time. These include: (a) trends in healthcare which dominated policies and priorities (the need for economic sustainability within the health sector; epidemiological trends; the explosion in new clinical and ICT technologies; patient safety and quality); (b) developments within the EU policy framework in particular the new Europe 2020 strategy made public in 2010 setting a new path for development for the coming decade at EU level; (c) the economic conditions characterized by the credit crisis and continuing financial fragility. Therefore, to reflect the change factors described above as well as the full diversity of SF projects, the case studies chosen for analysis came from different categories such as: integrated care, e-health and technology innovation and integration, healthy ageing, hospital development and redevelopment as well as overarching national/regional master plans. The case material gathered information through a qualitative assessment of programme documentation, policy studies and evaluation reports. Additionally, semi-structured interviews with key stakeholders were conducted for the investigated cases to make an account on how the project evolved as well as the factors hindering or facilitating these processes. The case material was gathered in various published and unpublished reports and articles [28] summarizing these experiences. The first part of the article synthesized the case material analysing the policy response across European countries with regards to using Structural Funds for health in the 2009-2011 programming period.

The latter project provided the research framework for the current ESIF programming period. This was based on document analyses of the Common Strategic Framework, the new ESIF Regulations, the Investments in Health Policy Guide for the European Structural and Investment Funds (ESIF) 2014-2020 [29] as well as other official documents on health inequalities or social determinants of health (Commission Communications, Action Plans, Reports, White papers, strategies, recommendations). It also took into account other toolkits developed by projects $[30,27]$. The documents were used to locate those interventions for health equity that are eligible for funding. Therefore, the second section of the paper presents those lines of possible investment within and beyond the health sector and across several social determinants of health. Content categories among the reviewed interventions were made based on: whether the intervention had a direct impact on health inequalities (they were mentioned or addressed directly in the policy document); whether they were indirect investments (in policy areas relevant to health equity such as employment, education; which are important health determinants); and other possible investments (such as innovation and technological development with weak, limited or circumstantial implications for reducing health inequalities).

\section{Results}

\subsection{What to pick up from the last programming period?}

Near to the start of the EUREGIO III project, analysis of the 2007-2013 National Strategic Reference Frameworks and Operational Programmes developed and funded by SF identified eligible health investments: directly in the health sector (healthcare infrastructure, eHealth, training, health promotion and access to services), investments in policies with a positive impact for health (employment, labour market policies, urban/rural development policies) and non-health sector investments (policies with potential impacts on wider determinants of health like innovation or environment) [31].

Nonetheless, case studies and evaluation reports of the EUREGIO III on health projects showed much of the focus of the programming and funds uptake was on health care infrastructure and e-health. The programme period reflected the legacy of reliance on a hospital-centric care model and centrist planning regimes in particular for those countries still emerging from the former Semashko era. Hospitals were generally poorly configured and in poor condition, a problem compounded by decades of underinvestment in infrastructure and clinical technologies. This locked planning and investment into tactical easement of immediate problems potentially at the expense of strategic, whole systems transformational change.

However, with the adoption of the Europe 2020 strategy towards the end of the financial period, there was a small shift towards more equity related actions such as improving the health for the elderly or disadvantaged populations or implementing health in all policies approaches. However SF represented here only a minor source of investment.

Challenges in using SF to tackle health inequities prevailed in: the little expertise about the SF processes as well as lack of experience and capacity to pursue health gains as an objective of other policy areas that are not health. A structural inhibitor came from a mono-fund approach requiring Operational Programmes to be financed either by ERDF or ESF. The two have had a different but complementary focus: one on growth, regional economies and infrastructure and the latter on investing in people, supporting employment and social inclusion. However, horizontal interventions for health equity required coordinated investments from the two areas of policies. Some case studies identified by EUREGIO III showed how these separate funding streams could be combined. In the Norbotten region, ERDF and ESF were used for an 'anytime anywhere' e-health infrastructure serving a highly dispersed rural population. In Berlin-Brandenburg region, the drive towards closer to home care was helped by adopting complementary priorities across sectors (transport, health, ICT) under the umbrella of a regional masterplan. This approach to pooling funding streams for integrated action has been picked up by the new framework that encourages synergies and integration between ERDF and ESF interventions.

Taking this learning into account, using SF for health equity meant relying on: either taking a health and equity in all policies approach to Structural Funds allocation; 
developing actions to improve the health of vulnerable groups (relating especially to goals such as employment and social inclusion), improving health systems in disadvantaged regions (health infrastructure, e-health solutions, strengthening primary health care, health promotion and disease prevention, improving access to services in rural areas and for socially excluded populations) or adopting whole systems improvements in the expectation that this would axiomatically incorporate vulnerable groups.

\subsection{Opportunities to address health inequalities within the current ESIF period}

In this current ESIF period, the eligible areas of investment have been brought together in a set of 11 Thematic Objectives (TO). As health has not been singled out as a priority, public health actions like health equity are funded as part of TOs which have as primary focus another policy area. This offers a wide range of investment opportunities, although they might seem hidden. In order to maximise ESIF potential to reduce health inequities the link between health equity and the TO should be explored. This part of the results section will provide the customized matrix of opportunities for investment in health equity under ESIF.

Direct investments for health equity have been explicitly mentioned within TO 9 "Promoting social inclusion and combating poverty". Poverty determines deep-seated inequalities inseparably linked to social exclusion and poor health [32]. Increasing the chances for the cycle of health inequalities and poverty to be broken requires a policy spectrum of interventions. These include:

a) Addressing risk factors prevalent in disadvantaged groups. Many health-related behaviours (tobacco consumption, alcohol, obesity) contribute to low health status and higher burden of disease among the disadvantaged population as they lack access to information, the financial means to a healthy life-style or proper access to treatment.

b) Investments in better living conditions for the vulnerable groups (in particular improved access to housing, water and sanitation, insulation, heating) have the potential to reduce exposure to health-damaging environments, combat social isolation and promote well-being.

c) Providing access to good healthcare and information where basic services are missing or not developed by: ensuring territorial access to health services, improving organization of care (availability of workforce, opening hours, waiting lists management), shifting focus from hospital-centred to a community-based model, empowering people to manage their own health (health literacy, e-health, telemedicine, consumer health applications). Most of the time people who lack access to health services are the ones who need them the most. Vulnerable groups have been specifically addressed within this line of intervention by supporting: affordable insurance coverage, access to affordable pharmaceuticals, vaccination, early detection, screening and treatment, investing in primary care especially maternal and infant healthcare as a key investment in a person's early start in life.
Actions that sustain collection of data, statistics and indicators on health inequalities are also encouraged as they help identify special attention groups, allow a personalized health management or support public reporting systems assess health systems performance.

Indirect investments are found in other TOs. TO2 "Enhancing access to and, use and quality of information and communication technologies "offers funding for innovation and digital growth, playing a part in tackling health inequalities occurring at an individual, professional and health system level. (a) For patients digital technologies like e-health can lead to empowerment through better access to data, higher health literacy and coproduction of health [33]. (b) For health and social services investments are available for information systems, electronic prescription systems or electronic patient medical records delivering more equitable, personalized care. (c) New ICT based solutions respond to the need to move away from hospital centered solutions through remote monitoring and ambient assisted living solutions for the elderly or vulnerable groups.

TO8 "Promoting employment and supporting labor mobility supports interventions for (a) active and healthy ageing (age-friendly settings for elderly workforce; prevention, screening and early diagnosis; measures for independent living) to respond to the ageing population and the impacts on labour-force participation. Actions that (b) view health as a human capital are also eligible: increasing awareness on health determinants; address vulnerable groups; focus on primary and secondary prevention; promote healthy life-styles in an intersectoral environment. (c) Health at workplace is also addressed here through interventions that: tackle work related risk factors; promote a healthy work environment; help recruiting people with impairments or disabilities. (d) Another eligible policy area is supporting health workforce to adapt to new competencies, roles and shifts in healthcare services: medical/nurse training programs on information technology, e-health and patient involvement; strengthening primary care specialists and general practitioners to help transition from hospital to community-based care; attract health professionals in rural/remote areas to improve access to healthcare.

T010 "Investing in education, skills and lifelong learning" adds to the aims of TO8 to support healthcare professionals by suggesting specializations in matters of: patient safety, life-style behaviours, chronic diseases, ageing and elderly care. Moreover, it promotes education for the general population having an important role in reducing health inequalities through: shaping socio-economic factors linked to educational attainment (income, occupation, inclusion in a social environment) or building awareness and health literacy.

T011 "Enhancing institutional capacity and ensuring an efficient public administration" is needed to support many of the system reforms and recommendations under the afore mentioned TOs (improving access to health, shifting the focus from hospital to community-based care, increasing the cost-efficiency of healthcare). 
Other possible investments for health, well-being and equity are found in TO 1, 3, 4, 5, 6, 7, TO1 "Strengthening research, technological development and innovation" can lead in the long run to more equitable health care with the help of new technology and clinical practice or to new solutions for the elderly or chronic diseases. TO3 "Enhancing the competitiveness of SMEs" can encourage the economic sector to address areas where the public system is lagging behind (personalized care for the elderly, assisting in functional physical or cognitive decline). TO4 "Supporting the shift towards a low-carbon economy in all sectors", T05 "Promoting climate change adaptation and risk prevention and management" and TO6 "Protecting environment and promoting resource efficiency" can provide a platform for interventions that address health risks within the environment, especially for people residing in vulnerable areas. TO7 "Promoting sustainable transport and removing bottlenecks in key network infrastructures" can enable people in rural/remote areas to access basic services and overcome isolation. Interventions for air quality, reduced traffic noise or bicycle routes constitute other examples.

\section{Discussion}

The main purpose of the paper was to explore how to maximise ESIF potential to reduce health inequities either by looking back at the lessons underpinned from the previous SF period or by identifying a range of direct or more hidden opportunities for action in the current framework.

When comparing the two financial periods there are indeed more opportunities for health equity investments now (Table 1). Investments for health can be directed to mitigate: increasing inequalities in health status among populations, the challenges of the elderly and the relative ineffectiveness of conventional healthcare systems. There was a shift in ESIF framework in terms of lines of intervention available from capital spending for infrastructure towards social and human values connected to health services. Health equity, healthy ageing, protecting the health of vulnerable groups were already embedded in the SF agenda before but with a modest representation in the funding stream. Now they become keynote dimensions for health investments funded by ESIF [34,35].

Table 1

Opportunities to address health and health equity under the 2007-2013 and 2014-2020 ESIF frameworks.

\begin{tabular}{|c|c|c|c|}
\hline & \multirow{2}{*}{$\begin{array}{l}\text { Lisbon strategy (2000-2010) } \\
\text { 2007-2013 }\end{array}$} & \multicolumn{2}{|c|}{ Europe 2020 strategy (2010-2020) } \\
\hline & & Financial period & 2014-2020 Financial period \\
\hline Areas of investment & $\begin{array}{l}\text { Healthcare infrastructure, } \\
\text { eHealth, training, health } \\
\text { promotion and access to services } \\
\text { - Policies with a positive impact } \\
\text { for health (employment, labour } \\
\text { market, urban/rural } \\
\text { development) } \\
\text { - Policies with potential impacts } \\
\text { on wider determinants of health } \\
\text { (innovation or environment) }\end{array}$ & $\begin{array}{l}\text { - Improving the health of } \\
\text { vulnerable groups (related to } \\
\text { goals like employment and } \\
\text { social inclusion) } \\
\text { - Health systems improvements } \\
\text { in disadvantaged regions (health } \\
\text { infrastructure, e-health } \\
\text { solutions, primary health care, } \\
\text { health promotion and disease } \\
\text { prevention, improving access to } \\
\text { services in rural areas/for } \\
\text { socially excluded populations) } \\
\text { - Whole systems improvements }\end{array}$ & $\begin{array}{l}\text { - Addressing health inequalities linked to } \\
\text { poverty and social exclusion } \\
\text { - tackling risk factors prevalent in } \\
\text { disadvantaged groups (tobacco } \\
\text { consumption, alcohol, obesity) } \\
\text { - better living conditions for vulnerable } \\
\text { groups (sanitation, water, insulation) } \\
\text { - access to good healthcare and information } \\
\text { where basic services are missing or not } \\
\text { developed } \\
\text { - Information and communication } \\
\text { technologies (e-health; information } \\
\text { systems: electronic prescription systems or } \\
\text { electronic patient medical records; ICT } \\
\text { based solutions to move away from hospital } \\
\text { centred solutions) } \\
\text { - Employment (active and healthy ageing; } \\
\text { health as a human capital; health at } \\
\text { workplace; supporting health workforce in } \\
\text { new competencies) } \\
\text { - Education (for healthcare professionals or as } \\
\text { a socio-economic determinant of health) } \\
\text { - Institutional capacities to support system } \\
\text { reforms } \\
\text { Policies with potential health gains } \\
\text { (research and innovation; enhancing the } \\
\text { competitiveness of SMEs; low-carbon } \\
\text { economy, climate change adaptation and } \\
\text { risk prevention; environment protection; } \\
\text { sustainable transport) }\end{array}$ \\
\hline \multirow[t]{3}{*}{ Remarks } & $\begin{array}{l}\text { Health is a direct investment } \\
\text { priority. }\end{array}$ & $\begin{array}{l}\text { Modest investments in health } \\
\text { equity mainly: health in all policies } \\
\text { approaches and addressing } \\
\text { vulnerable groups. }\end{array}$ & $\begin{array}{l}\text { Health is no longer a specific investment } \\
\text { priority. }\end{array}$ \\
\hline & $\begin{array}{l}\text { Investments are focused mainly on } \\
\text { health infrastructure. }\end{array}$ & & $\begin{array}{l}\text { Health equity investments are primarily linked } \\
\text { to combating poverty and social cohesion, } \\
\text { although health gains can be found in all ESIF } \\
\text { areas of investment. }\end{array}$ \\
\hline & Mono-fund approach. & & Synergies of ERDF and ESF. \\
\hline
\end{tabular}


However, despite these opportunities there are also challenges in making use of the ESIF potential. Although, the financial crisis created greater visibility at European level for health equity [7], it also drove many Member States to reduce their public spending for social policies. This can make it difficult to promote social inclusion as a priority at higher governance levels and secure national support and contributions for ESIF applications.

The implementation of ESIF is to a higher degree decentralized. The European Commission coordinates the thematic priorities as agreed with the Member States but the responsibility for resource allocation across priority areas remains within national authorities. What becomes very clear is that the ministries of health and the public health community are essential to make use of the ESIF and that they should engage more to maximise this potential.

The framework of opportunities described in the results section of this article often implies the public health community will need to take a heath in all policies approach or establish policy synergies between thematic priorities. However, multisectoral division of powers and authority, coordination of goals and agendas as well as integration of public investments between different line ministries, agencies, private sector and civil society remain a challenge [36]. It remains debatable if the need for investment will be a facilitating resource for change. The impact of the crisis can hinder integration as stakeholders try to secure their share of funding and maintain their organizational or professional identity. At the same time it can also have the opposite effect if sectors adopt a transformative approach and overcome barriers, cooperate for a common goal and make better use of the resources available [37].

There are also political challenges to consider. Structural Funds are often associated with pursuing political aims and creating visibility among the electorate with regards to important investments. Unlike the previous infrastructure investments, in the case of reducing health inequities demonstrating a clear, tangible return-on-investment might prove more difficult. They are investments in the future and require a longer time, not just within one ESIF cycle or an electoral term, to produce transformational change. Therefore, the question that arises is to what extent politicians in Member States and regions, often risk-averse and looking to secure support, will actually change their policies towards whole systems reforms like measures for health equity and face public scrutiny?

In some cases it is even hard to anticipate to what extent these interventions will lead to actual reduction in inequalities and not increase them. When analysing the thematic objectives, we identified most lines of interventions for health equity focused on disadvantaged, vulnerable or excluded population (the poor, migrants and ethnic minorities, the elderly, children). Despite a strong ethical rationale, a policy spectrum with a focus on vulnerable groups only are often not enough to reduce inequalities and sometimes on the contrary can deepen them [38-40]. Interventions aimed at the most disadvantaged that require change in behaviour (health promotion, prevention) or individual mobilization of resources do not always address the root causes of disadvantage while the better off benefit more from these policy interventions. At the same time, universalistic policies might favour the middle classes but not reduce health inequalities on their own. Therefore, population-based policies with high-atrisk groups strategies should be combined in integrated approaches.

There is the need for an evidence based/informed approach to policy making and decision-making, especially when tackling such a multifaceted problem like health inequalities. In policy making, choices for investment are rarely the outcome of informed critical assessment of evidence but rather follow a garbage can approach where project proposal come as a consequence of politics, ad-hoc availability, organization requirements and ways to frame problems. Moreover, ESIF, as many forms of distributive policies, can lead to targeted approaches to programming due to its structure on thematic objectives. To prevent decision makers from choosing between policy lines of intervention rather than on a route map or an integrated approach, public health should play a more active role in the ESIF programming cycle to achieve coordination and synergies during implementation later on.

\section{Conclusions}

ESIF offer new opportunities to reduce the unfair gaps between populations, provide them with the chance to live healthy, independent lives and to be able contribute to economic growth. The findings of this article describe the specific lines of intervention eligible for investment such as: enhancing people's access to healthcare where this is missing or underdeveloped, addressing risk factors that contribute to low health status, especially for the vulnerable groups, investing in critical forces that can improve health such as encouraging employment, education or sustainable transport.

This map of opportunities has considerably changed since the last EU programming period and it remains to be seen to what extent the new opportunities will be met with the must needed capacity development, institutional and political support. The public health community needs to look beyond those operational programme priorities that carry a health label and adopt a transformative approach of cooperation with other sectors for common goals. This can be achieved by employing health in all policies approaches, policy synergies or integrated approaches. At the same time the potential ESIF holds for health equity needs to be understood by decision makers at national and local levels as well. The discrepancy between long-term strategic interventions for health equity and political priorities for solutions with immediate visible results can make the policy setting for health equity difficult. Efforts should be made to incorporate evidence approaches in policy making which can prove impact and demonstrate responsible governance but also ensure these policies reach their intended aims.

\section{Conflict of interest}

The authors whose names are listed above certify that they have NO affiliations with or involvement in any organization or entity with any financial interest (such as 
honoraria; educational grants; participation in speakers' bureaus; membership, employment, consultancies, stock ownership, or other equity interest; and expert testimony or patent-licensing arrangements), or non-financial interest (such as personal or professional relationships, affiliations, knowledge or beliefs) in the subject matter or materials discussed in this manuscript.

\section{Acknowledgements}

This article arises from the EUREGIO III project and the HEALTH EQUITY 2020 project which have received funding from the European Union, in the framework of the Health Programme.

\section{References}

[1] Marmot M, et al. Report on health inequalities in the EU. Luxembourg: European Commission Directorate-General for Health and Consumers; 2013.

[2] OECD. OECD regions at a glance 2013. OECD Publishing; 2013.

[3] European Commission. Report on health inequalities in the European Union (SWD 328); 2013 http://ec.europa.eu/health/ health_structural_funds/docs/esif_guide_en.pdf.

[4] Tamamović A. The impact of the crisis on fundamental rights across Member States of the EU-comparative analysis. Brussels: European Parliament, Directorate General for Internal Policies; 2015.

[5] Bacigalupe A, Escolar-Pujolar A. The impact of economic crises on social inequalities in health: what do we know so far? International Journal for Equity in Health 2014;13(1):52

[6] Suhrcke M, Stuckler D. Will the recession be bad for our health? It depends. Social Science \& Medicine 2012;74:647-53.

[7] Ruckert A, Labonté R. The global financial crisis and health equity: toward a conceptual framework. Critical Public Health 2012;22(3):267-79, http://dx.doi.org/10.1080/09581596.2012.685053.

[8] European Commission. Commission communication: solidarity in health: reducing health; 2009 http://eur-lex.europa.eu/ LexUriServ/LexUriServ.do?uri=COM:2009:0567:FIN:EN:PDF.

[9] European Commission. Commission staff working document investing in health (SWD 43); 2013 http://ec.europa.eu/health/ strategy/docs/swd_investing_in_health.pdf.

[10] Randall E. European Union Health Policy with and without design: serendipity, tragedy and the future of EU Health Policy. Policy Studies 2000;21(2):133-64, http://dx.doi.org/10.1080/713691365.

[11] CSDH. Closing the gap in a generation: health equity through action on the social determinants of health. Final report of the Commission on Social Determinants of Health. Geneva: World Health Organization; 2008.

[12] WHO Regional Office for Europe. How health systems can address health inequities through improved use of Structura Funds. Copenhagen: WHO; 2010 http://www.euro.who.int/__data/ assets/pdf_file/0007/129868/e94606.pdf.

[13] Bambra C, Gibson M, Sowden A, Wright K, Whitehead M, Petticrew M Tackling the wider social determinants of health and health inequalities: evidence from systematic reviews. Journal of Epidemiology and Community Health 2010;64(4):284-91.

[14] Whitehead M. A typology of actions to tackle social inequalities in health. Journal of Epidemiology and Community Health 2007;61(6):473-8, http://dx.doi.org/10.1136/jech.2005.037242.

[15] Diderichsen F, Evans T, Whitehead M. The social basis of disparities in health. In: Evans M, Whitehead F, Bhuiya B, Wirth M, editors. Challenging inequities in health. Oxford University Press; 2001.

[16] Mackenbach JP, Meerding WJ, Kunst AE. Economic costs of health inequalities in the European Union. Journal of Epidemiology and Community Health 2011;65(5):412-9.

[17] Stuckler D, Basu S, McKee M. Public health in Europe: power, politics, and where next? Public Health Reviews 2010;32(1):213-42.

[18] Council of European Union. Council conclusions on the reflection process on modern, responsible and sustainable health. Brussels: European Union; 2013. Retrieved from http://data.consilium.europa.eu/doc/document/ST-17871-2013INIT/en/pdf.
[19] European Commission. Reducing health inequalities in the European Union. Luxembourg: Directorate-General for Employment, Social Affairs and Equal Opportunities; 2010. Retrieved from data.consilium.europa.eu/doc/document/ST-17871-2013INIT/en/pdf.

[20] European Commission, Economic Policy Committee. Joint report on health systems. European Economy Occasional Papers nr 74. Directorate-General for Economic and Financial Affairs; 2010 http://europa.eu/epc/pdf/joint_healthcare_report_en.pdf.

[21] Council of the European Union. Council conclusions on equity and health in all policies: solidarity in health. Brussels: European Union 2010. Retrieved from http://www.consilium.europa.eu/uedocs/ cms_data/docs/pressdata/en/lsa/114994.pdf.

[22] Stegeman I, Kuipers Y. Health equity and regional development in the EU. Applying EU Structural Funds. Brussels: EuroHealthNet; 2013. Retrieved from http://fundsforhealth.eu/wp-content uploads/2013/11/Final_EA_Regional_SF_Review_Report.pdf.

[23] Greer SL. Everything you always wanted to know about European Union health policies but were afraid to ask. The European Observatory on Health Systems and Policies; 2014.

[24] healthequity2020 (2015, 02 19). Retrieved from www.healthequity2020.eu/.

[25] action-for-health. (2015, 02 19). Retrieved from www.action-for-health.eu/.

[26] Health Gain. (2015, 02 19). Retrieved from Impact of Structural Funds on Health Gains: http://www.healthgain.eu/.

[27] esifforhealth (2015). Retrieved from http://www.esifforhealth.eu/euregio3. (2015, 02 19). Retrieved from www.euregio3.eu (Accessed 20.07.15).

[28] Dowdeswell, B. (2011, 12). EIII Case study material. Retrieved 10 16, 2016, from http://euregio3.eu/, http://euregio3.eu/pages/ existing-knowledge-learning-using-sf-health-investments/ learning-resources/eiii-practical-knowledge-database/eiii-casestudy-material/.

[29] European Commission. Investments in health policy guide for the European Structural and Investment Funds (ESIF) 2014-2020; 2014 http://ec.europa.eu/health/health_structural_funds/docs/esif_guide_ en.pdf.

[30] fundsforhealth (2014). Retrevied from http://fundsforhealth.eu/ (Accessed 10.07.15).

[31] Watson J. Health and Structural Funds in 2007-2013: country and regional assessment. Directorate-General for Health and Consumers; 2009 http://ec.europa.eu/health/health_structural funds/docs/watson_report.pdf.

[32] WHO. Closing the gap in a generation-health equity through action and the social determinants of health; 2008 http://whqlibdoc.who.int/publications/2008/9789241563703_ eng.pdf?ua=1.

[33] Needham C, Carr S. Co-production: an emerging evidence base for adult social care transformation. Social Care Institute for Excellence; 2009. Research Briefing 31.

[34] Docteur E, Berenson RA. In pursuit of health equity: comparing U.S. and EU approaches to eliminating disparities. In: Timely analysis of immediate health policy issues; 2014

[35] Watson J, Dowdeswell B. New perspectives on the application of health care related Structural Funds; 2011 http://wiki. healthclusternet.eu/download/attachments/6260097/EUREGIO+III+ Position+Paper.pdf.

[36] Van Raak A, Mur-Veeman I, Hardy B, Steenbergen M, Paulus A, editors. Integrated care in Europe: description and comparison of integrated care in six EU countries. Maarssen, The Netherlands: Elsevier Gezondheidszorg; 2003.

[37] Glasby J. Integrated care in a cold climate. International Journal of Integrated Care 2010;10:e001.

[38] Capewell S, Graham H. Will cardiovascular disease prevention widen health inequalities? PLoS Medicine 2010;7(8):e1000320, http://dx.doi.org/10.1371/journal.pmed.1000320.

[39] McLaren L, McIntyre L, Kirkpatrick S. Rose's population strategy of prevention need not increase social inequalities in health. International Journal of Epidemiology 2010;39(2):372-7, http://dx.doi.org/10.1093/ije/dyp315.

[40] Blaxter M. Evidence for the effect on inequalities in health of interventions designed to change behaviour. Bristol: Department of Social Medicine, University of Bristol; 2007. 